\title{
RAIL AS A NATURAL MONOPOLY AND POSSIBILITIES OF ITS REGULATION
}

\author{
Forgács Anna $^{(1)}$ - Szabó Szabolcs ${ }^{(2)}$
}

(1) Associate professor, Budapest Business School, College of International Management and Business, Department of Entrepreneurship and Human Resources, Ph.D student,

${ }^{(2)}$ Szent István University, Faculty of Economics and Social Sciences

E-mail: Forgacs.Anna@kkk.bgf.hu, szabo.szabolcs2@,freemail.hu

\begin{abstract}
Government regulation is required for goods with a gap between social and private costs and social and private benefits. Such goods can be classified into three types:

a) toll goods, which are non-rival but exclusion from use is possible;

b) common pool goods, which are privately consumed and exclusion is not possible;

c) collective goods, which are jointly consumed and exclusion is not possible.
\end{abstract}

Toll goods (the railway for example) are characterized by the need of a significant amount of capital and an almost zero marginal production cost. As one single asset is enough to meet the entire public demand, providers of such services can be defined as natural monopolies and as so the issue is to avoid those monopolies to supply scarce services at high prices. Efficient regulation requires the government to stand apart from and an independent regulatory agency to restrict monopolist operation. This regulatory task can be accomplished by simulating competition (price cap regulation) or by motivating competition (free access to networks).

We address this issue focusing mainly on the Hungarian railways.

Keywords: railway, public costs-private costs, natural monopoly, price cap regulation JEL classification: $R 41$

\section{Intorduction}

According to related literature, goods where social or private costs or social or private benefits respectively differ significantly require state regulation. These goods have three basic types:

- Toll goods where non-payers are excludable

- Common pool goods, where potential non-payer beneficiaries cannot be excluded rationally and which are consumed individually and

- Public goods, where no one can be excluded from consumption and are consumed collectively.

Services provided by network industry (to which rail is part, too) belong to the group of toll goods, characteristically requiring large capital and functionally behaving as natural monopoly. Decreasing marginal cost (average cost) implies the charge of higher prices and insufficient quantity of supplies, would not the state to prevent it with legal regulations and by operating independent regulatory agencies. The state may fulfil this role through stimulating market (by price cap regulation) or through promoting competition (by free access to networks). This means that all possible efforts should be made that the given service would be provided via a single (and practically short) network and that the service operator is bound by law to ensure the use of infrastructure capacity for other railway undertakings to employ cost-based pricing 
and to maintain the prices by price cap regulation, respectively; thus realizing the competition of service providers. (Csillik at al., 2000)

In the mid- or post-crisis state of world economy, optimizing the use of resources at the macro level by economic regulations still remains a crucial question. Transportation emerges as key sector as further increase in world trade, and a strong expected increase in demand for infrastructural capacities, of which the railway service is a high priority factor. Bearing in mind the above logic let us look into the current state and future of the Hungarian rail.

\section{Logistics-Transportation-Rail}

The process of globalization has accelerated, and boosted increased international factor movements, resulting in explosion in logistics services. To a big proportion logistics mean transportation (it is $44 \%$ in the EU), that is, the use of transport infrastructure, in which rail plays a significant role. The final aim of our research is to reveal the possibilities of optimizing the operation of Hungarian railway transport (freight and passenger transportation) by regulations. To achieve this, first we summarize the relation between logistics and economic growth (GDP), trends and figures in logistics; then the role of transport played in it. Finally, we break down transport into its elements highlighting rail as one of them. Our overview is primarily taken from EU aspect. We will also discuss the questions of developing infrastructural capacities as the crisis brought the strengthening of opinions, seeing the possibility of recovery in (mainly state-financed) infrastructure developments (Krugman,2012; Duncan, 2012), emphasizing transportation infrastructure capacity priority. McKinsey Global Institute for example, named transportation infrastructure investments as a potential game changer. At their estimate, an additional 1\% pof the GDP spent on this purpose will increase economic growth by $1,8 \%$ (Lund et al., 2013). This paper serves as a preliminary study to a larger research which would analyse the possibilities for optimizing Hungarian rail transportation, with special regard to the operation or closedown of side railway lines.

\section{Logistics}

In high-income economies, logistics plays a key role in securing sustainable mobility, also contributing to realizing such goals as clean environment or energy safety. (European Commission, 2006)

In the USA,-logistics costs have stayed at a stable 8-10\%-of the GDP in the last decade (Gilmor, 2014), In the EU we see a slightly lower percentage around 6-7\% (it will be approximately a yearly 900 billion in Euros) (European Commission, 2015). Hungary has a narrower logistics market. In 2012, according to the EU the value of logistic costs reached, 4,2 billion Euros which is barely higher than $4 \%$ of the GDP.

A considerable part of logistics costs (some 60-65\%-a) is freight transportation cost, (Schulz, 2014) 40-50\%-is passenger transport (European Commission, 2015). The flow of goods among companies and the demand for freight required to implement this flow defines the division of labour at the given supply-chain, i.e. vertical integration (depth of manufacturing) and appointed stocking locations including the quantity of stock. Supply-chain management aims to optimize activities taking part in the activities, so to analyse and define fright and other services it is essential to know the anatomy of the given supply chain. Those freight services which can adapt to the new requirements in demand represent a bigger proportion, but other branches can adapt less, this way they do not provide eligible services. 
Although the rapidly increasing freight transport contributes to the growth of economy and job creation, it also causes negative externalities such as bottlenecks, casualties, environmental pollution, and a stronger dependence on hydrocarbon import. As the infrastructure capacity is scarce and economy has a strong demand for it, serious bottlenecks may occur unless appropriate measures are taken to optimize transport. Logistic approach has to be integrated into transport policy and this policy should be shaped to meet the economic challenge of our days, at the same time handling negative impacts as well.

„Logistics centres of huge capacity and having the ability to create added value have emerged in recent decades. These centres have become network nodes between the co-operating organizations which accomplishthe management of supply chains (networks) by connecting different modalities and networks with their infrastructure and informatics." (Karmazin, 2015)

\section{Transport}

Globalization and the EU enlargement requires new European transport policy. The transport sector employs more than 10 million people in the EU (4,5\% of employment) and amounts to $4,6 \%$ of the GDP (Eurostat). The European Union gives prominence to transport policy, but as earlier it has been marked by liberalization and harmonization, now other priorities have also emerged. The single European transport area is in focus with high-standard transport services in all member states and sustaining the competitiveness of the EU.

In order to achieve the main goals drawn up in the Lisbon strategy (economic growth and job creation) it is essential to create the single European transport area, the completion of the internal market, to secure sustainable growth, to expand the transport networks throughout the entire continent, to improve transport safety, and to strengthen international cooperation. Transport policy is one of the first common areas of sector policy within the EU, but only the last decades have seen significant changes in it. The idea of the establishment of a transEuropean network and the requirements for environmental protection appeared in the Maastricht treaty in 1992. The central issues of the White Paper of Maastricht of 1992 were sustainable mobility and the opening of transport markets to competition. The White Paper of 2011 'Roadmap to a Single European Transport Area - Towards a competitive and resource efficient transport system' (European Commission, 2011) included the action plans indispensable to the completion of the internal market (integrated transport network, elimination of scarcity, infrastructure development for the countries joined in 2004, cutting carbon emission, reducing dependence on imported oil) (European Commission, 2014). The EU supported the completion of goals in transport policy with legislation as well. The aim of transport laws is the integration of national markets on one hand, on the other hand, entry to the market, also promoting access to infrastructure capacities and compatible technical standards, eliminating the technical and administrative barriers that impede competition. Key elements to legislation are the four railway packages that further we will discuss in detail. Infrastructure must be extended and modernised in many ways for creating the trans-European transport network, (TEN-T), which facilitates a technologically front-rank, resource-efficient and environment-friendly transportation.

The aim of the supply chain management that optimizes the activities in the chain all together. So the knowledge of the structure of a supply chain given so essential to the definition to the definition and analysis of transportation service. (Horváth-Pónusz, 2011) 


\section{Railway}

European railway policy is shaped to the general transport policy, aiming at creating the single Europe and the free movement of factors through the liberalization of the market and structural reforms. Here we summarize the history of railway policy in brief, paying special attention to the two core elements in the aspect of creating market conditions: free and non-discriminatory access to infrastructure capacities and charging principles (price regulation).

\section{EU regulation of network industry}

Until the 1980s the network operators in Europe functioned in social roles as well. Therefore, in most cases they had exclusive rights, they were public property and a ministerial apparatus exercised legislative and supervisory power. The emergence of new technologies, competitors' threat, and the growing difficulties in financing the expanding services led to the need for involving private capital as well. The EU created supranational regulations, with reform waves embodied in directives.

The main goals of the first wave of directives (from 1998) were opening the market, elimination of the exclusive rights for services, and to harmonize transport sector and competition regulations. A group of the member states quickly adopted the directives, but in several member states this process was a lengthy one and although each member state setup their own independent regulatory agency, their competence was not clarified entirely. (Valentiny, 2013) 2002-2004 was the period of acceleration, the directives adopted during the second wave of reforms advanced opening of the market and in the period between 2007 and 2009 further steps of harmonization were taken towards a single European market. (Baldwin, 2013)

\section{Rail regulation in the $E U$}

By the beginning of the 1990s the railway companies were state monopolies in most of the member states (in several member states they still are), and railway transport both in its regulations and technical standards strongly differed by member states. By the end of the $80 \mathrm{~s}$ the opening of the internal market and the growing competitiveness of road freight transport put railway under pressure. The 91/440/EEC directive about the development of the Community's railways stated that railway undertakings and infrastructure operators shall become independent from the state (with separate assets, accounting and budget), and the access to infrastructure capacity shall be secured in non-discriminatory and transparent way. The user fee shall be charged by the infrastructure manager and be payable by the railway undertakings. The directive about establishment of railway undertakings was created, then the 95/19/EC directive on the allocation of railway infrastructure capacity and the charging of infrastructure fees as well. The regulations of the latter were ambiguous, resulting in different practices in different member states. After this, the four Railway Packages followed in which, through separating the infrastructure and the operation, the liberalization of the sector, especially that of the freight transport were taken into account by the legislation.

The first railway package which aims at the liberalization of the freight transport market (2001/12-13-14/EC directives) regulated the principles of the allocation of railway infrastructure capacity and the charging of infrastructure fees. The directive instructed transparent and non-discriminative allocation of capacities and it defined the scope of services the rail operators shall provide for the railways undertakings on a non-discriminatory basis, and what principles they shall adopt when determining transport fees. 
The second railway package, drafted in 2004, is characterized by market opening, transport safety and interoperability. The 2004/51/EC directive includes the goal of the full rail freight market opening of the continent, the 2004/49/EC records the Community's railway safety standards to consider when creating the national safety rules, the intention to improve and integrate those rules, and the $881 / 2004 / \mathrm{EC}$ regulation is about the establishment of the European Railway Agency. The Agency has been established to provide the EU member states with technical assistance in the fields of railway safety and interoperability.

The third railway package (2007) contains the proposal to open up the international passenger transport market by 2010 , instructing that any railway companies with operational licence and certificate of safety may enter international passenger transport market. The third package includes 2007/58/EC directive on the development of the Community's railways and the 2007/59/EC directive.

On the certification of train drivers and the regulation of passenger rights was adopted.

The fourth railway package is a new (perhaps final) phase of the market opening process, aiming at promoting competition and innovation and implementing structural and technical reforms towards the establishment of single European railway area. The main contents of the package are proposals of the EC: $2013 / 0014 /$ COD is a proposal for revising the regulation on the European Railway Agency, 2013/0015/COD is a proposal for revising the interoperability of the rail system within the European Union and 2013/0016/COD would revise the directive on railway safety (European Commission, 2015). This package sets out four areas of reform:

- technical standards and licences (reducing administrative barriers to entry to market);

- a functioning structure meeting the requirements (separation of the user and the operator of railway network);

- opening up internal passenger transport market (public service contracts should be awarded through tenders), ensuring non-discriminatory and efficient access to railway vehicles);

- retaining skilled workforce (protection of employees by obliging railway companies with awarded public service contracts to take over crew) (Koós, 2013).

In part two we reveal the performance of Hungarian railway on the strongly competing transport market within the above discussed community regulatory frame.

\section{The Hungarian Railway}

In the economically developed regions of Western Europe, transport policies emphasise the importance of developing high-speed traffic systems, therefore, networks are shaped which generate connections among one another. Central and Eastern European countries represent a minor market possibility. Internationally, the quality of rail networks, the standard of vehicles and services shows substantial differences. The reason for such diversion is the economic and social condition in particular. Outstanding partners of Hungary includes Austria, Germany, and Romania, where $60 \%$ of international passenger traffic takes place.

In the Western regions of Hungary a tendency of growth can still be appreciable for the railway industry (for example: new railway carriages, extended Wi-Fi accessibility). Only by considering local efforts for development, ensuring modern vehicles and high standard services might these potentials effectively used. Nevertheless, the continuous defaults in improvements does not enable the railway industry in Hungary to preserve its market share. Here, in the 
Western regions of Hungary, threats are also present, since on some lines even market based passenger transportation services might be available

\section{The Tendencies of Hungarian Passenger Transportation}

On the private premises of the Hungarian railway network only MÁV-START Ltd. and GySEV Ltd. operate. The efficiency in passenger transportation of MÁV-START Ltd. between 1991 and 2011 shows an almost constantly decreasing trend. A slight increase appears in 2001 and 2002, then between 2003 and 2006 the number of passengers transported by MÁV-START Ltd. stagnates, though from 2007 a major set-back occurs. In 2010, statistics shows only 137,3 million people. The trend, which meant less passengers, reversed in 2011 and by 142 million people, this has been the highest rate of efficiency in the last four years. (Figure 1.)

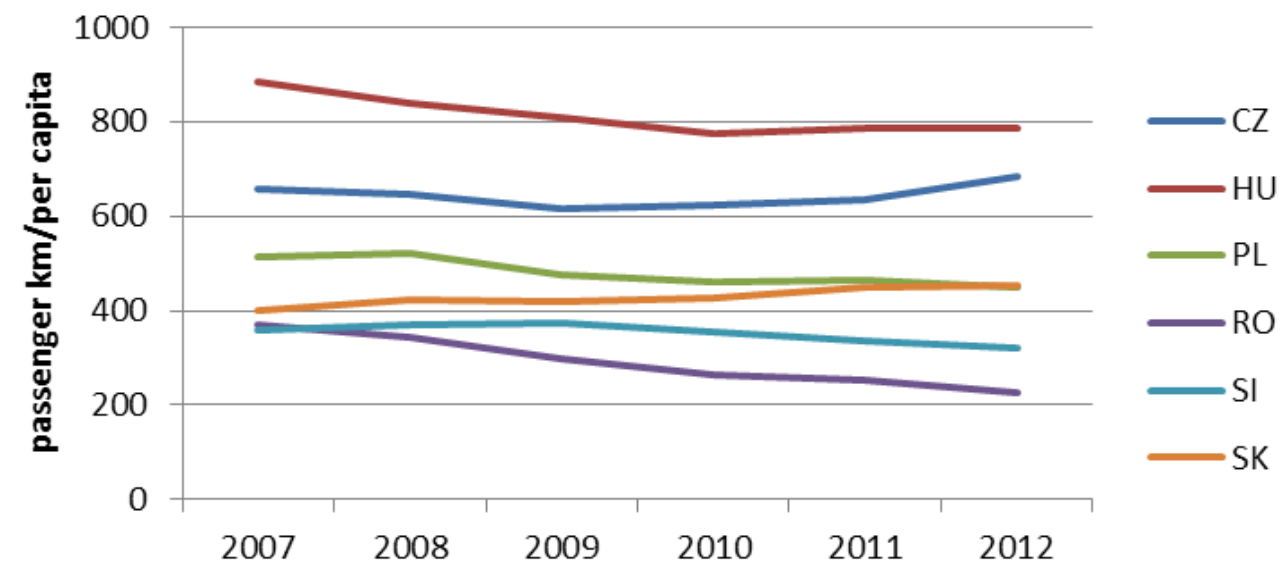

Figure 1. Passengerkm/person, in comparison with countries from the same region Source: based on Eurostat, self-edited

The trend of passengerkm values corresponds to the changes in the values of calculated number of passengers. Consequently, the average distance of journeys did not change significantly over the last few years and from this point of view, passenger transportation shows stability. (Figure 2.)

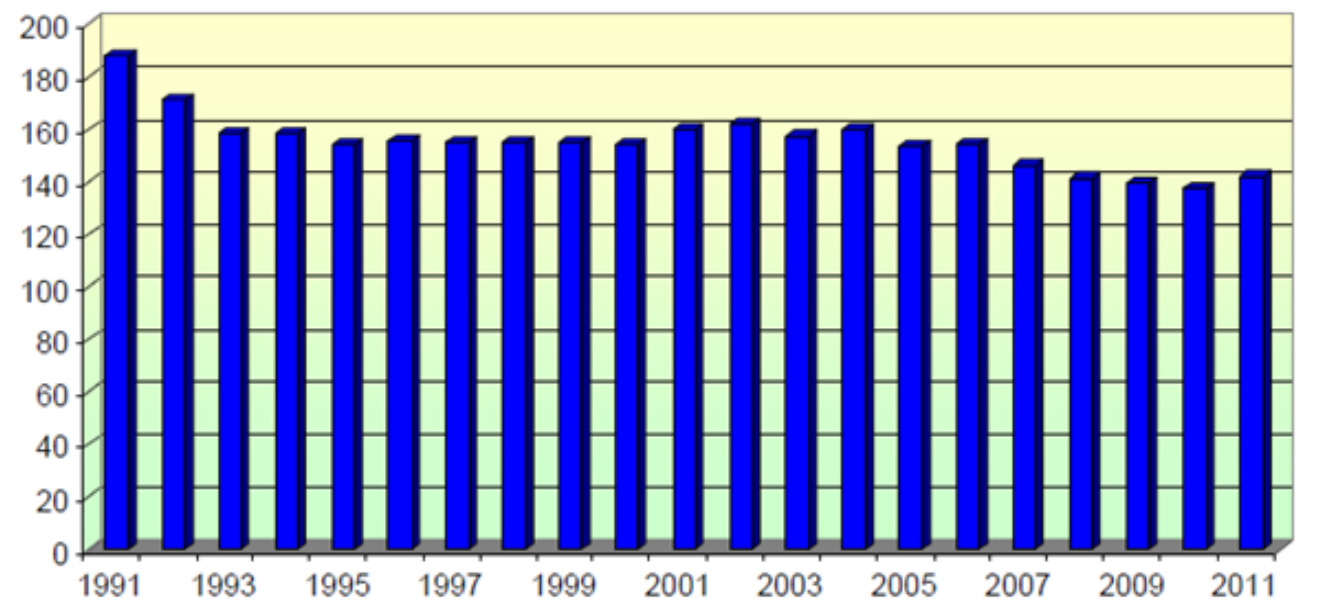

Figure 2. The calculated number of passengers transportedin Hungary between 1991

Source: NKS, 2013 and 2011 (million passengers) 
Examining the domestic and international performance separately, it is concluded that the factors affecting these two regions are different, thus their efficiency also differs. Analysing passenger transportation in a longer period of time, it is noticeable that following the changes in economic structure in the early 90's, similarly to other countries in this region, a severe setback took place in the number of passengers transported.

Compare to the top performances of the 70's and $80^{\prime}$ the number of passengers transported annually was cut in half and stabilized around 150 million/year in 2000. (Figure 3.)

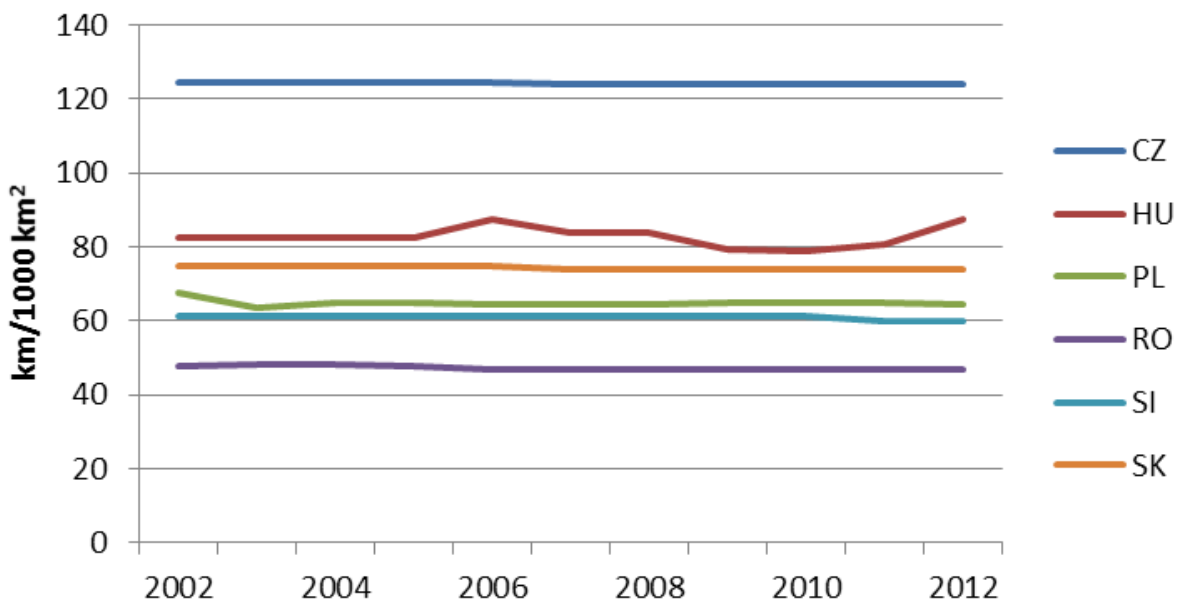

Figure3. Railway track density $(\mathrm{km} / \mathbf{1 0 0 0 k m 2})$

Source: based on Eurostat, self-edited

\section{Transportation of Goods on the Hungarian Railway}

Railways and roads play a crucial role in the transportation of goods in Hungary. The concentration of railway freight is high, however due to private railway companies it decreases. The market barriers to entry are higher, compared to public roads and new entrants are primarily focusing on the single wagon load segment. Also, problems with interoperability are significant, which is disadvantageous to the market competition.

The volume in the transportation of goods on railway started to decrease from the 80's, but freight on roads increased. Following the EU accession, Hungary reached a ration in the division of labour which is the characteristic of Western-European countries (modal split). In 2011, the 50,937 billion ton-kilometre (tkm) efficiency in the transportation of goods divide as follows: the share of inroad transportation was $68 \%$, railway $18 \%$, delivery by pipeline $11 \%$, shipping 4\% (source: NKS, 2013). The neighbouring countries, excluding Austria, had similar percentages in the road and railway shares.

The white book of the EU transport policy in 2011 set an objective that by 2030 the $30 \%$, and by 2050 the $50 \%$ of road freights, longer than $300 \mathrm{~km}$ should be replaced by other means of transportation (for example: railway or shipping). Considering the size of Hungary, it may be a challenge, especially since the way of transportation is defined by the owner of goods or the assigned logistic company.

In Hungary, the change in the structure of the economy right in the beginning of the 90's and its negative effects lead to an extreme decrease in the transportation of goods. Compared to the 70 's and 80's top performances, transported tons of goods on railway was reduced to its third. 
The changes after the shift in economic structure and the opening of free markets (for example: decreasing production volumes, bankruptcy of industrial branches, the collapse of the Eastern market, the demand of SME for transporting goods on roads, competitive carriers) lead to the set-back in the performance of the transportation of goods on railway. It stabilized on a much lower level, thou it has a decreasing tendency ever since.

Considering the data of the Hungarian Central Statistical Office from 2012. I-III. quarters and the tendencies in 2011, it seems two thirds $(66 \%)$ of the goods transported by companies registered in Hungary was transported in road. This means 11 million inland trucks (132 tons of goods) and 1,7 million trucks internationally (34 million tons of goods). nly $20 \%$ of the goods were transported by railway in 2012. According to the own research of the MLSZKSZ the Hungarian intermodal transportation (including Ro-La) scarcely reached 10-13\% within the railway transportation branch, while this proportion in Western European countries was 20$25 \%$. (Figure 4 .)

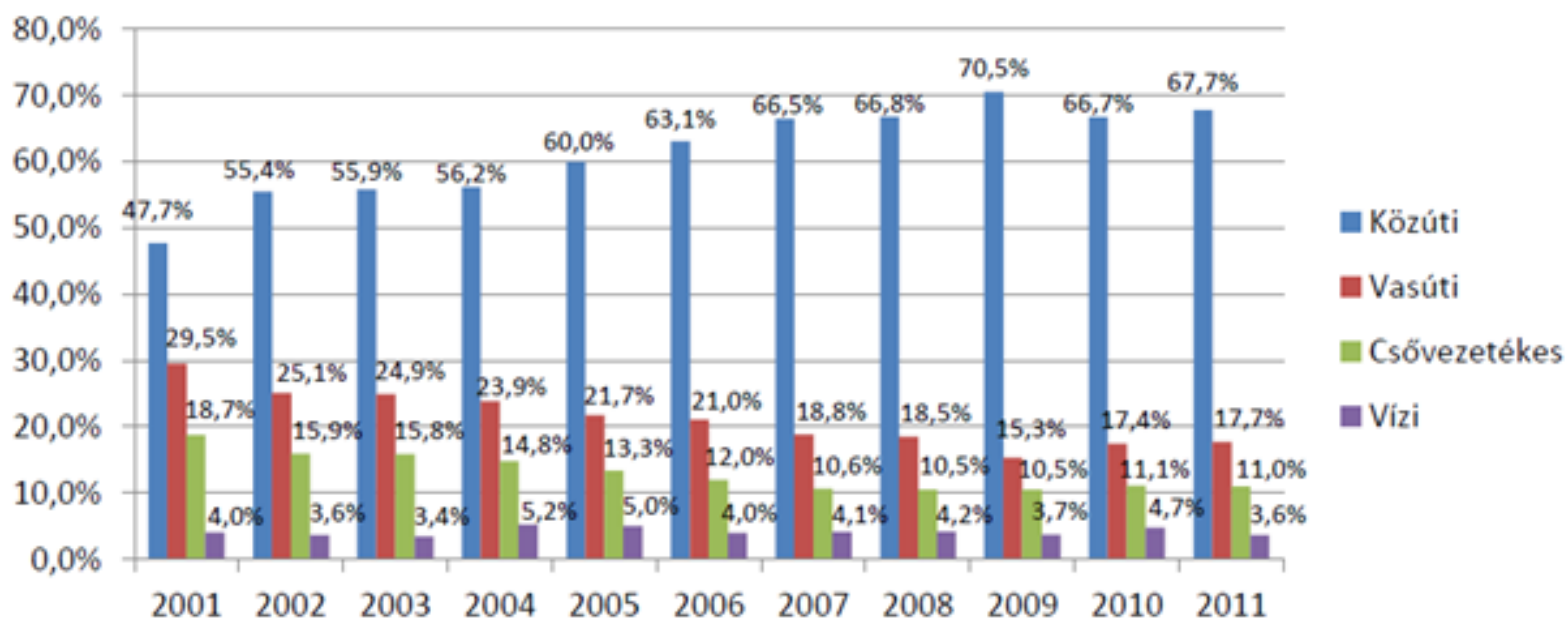

Figure 4. The Hungarian division of labour in the transportation of goods from 2001 to 2011

Source: Hungarian Central Statistical Office

\section{Suggestions}

According to the European Commission, as a part of the fourth railway package, railway companies get access to the infrastructure in all EU countries in order to enable inland railway services in passenger transportation as soon as the 1st of January in 2017. The proposed liberalization of passenger transportation may severely influence Hungarian railway companies. The introduction of such market competition is only advantageous for railway companies at a higher technical standard with financially favourable environment. Open borders might become a competitive disadvantage for Central European railways.

As a result of their aggressive market strategy, well-funded competitors might easily become dominant on the market that would trigger spiralling prices or it may significantly pull down supplies. Considering the difficult financial situation, low prices are not to be competing with, which might also results in a monopoly situation of new market entrants.

In Hungary, the lower standard of services and the lack of intermodality together means a weak competitiveness compared with in road transportation. In the absence of a general scheduled timetable is untraceable for passengers. Railway traffic is incalculable, while the rigid system 
does not respond eligibly to social and market challenges. The insensitivity for the market results in subsequent loss in the division of labour.

A more and more significant involvement seems to be present in the suburban railways of Budapest due to recent developments. "House to house" traveling, which can be organized as one single route in long-distance traveling, is optimized for intersections of transfer and the integration of a well-structured scheduled is in process. On the renewed lines, intermodal connection is assured, therefore an increase in the number of travels is appreciable in this segment. Among others, it is due to the constantly renewed railway carriages that the railway transportation of passengers is socially accepted and the comfort of travelling is significantly increasing.

Because of the requirements in environmental and energy efficiency, but also these factors being socially accepted, demand rises for railway services. High standard and customer focused railway services are created. By developing international corridors in long-distance travelling market share could be extended.

Without the measures influencing the division of labour and the prolificacy of a self-controlling set of rules, new competitors appear so a loss in market shares will be evident in both passenger transportation and the transportation of goods. Because of the rapidly worsening competitiveness, transit traffic will be diverted to other neighbour countries. Targeted measures including the modernization of safety rules and its homogeneity. Lacking these, the favourable tendency in the safety of transport cannot continue in the long run, therefore it will be underdeveloped comparing it with the EU average.

According to the strategies in passenger transport on railway, considering the opening of markets, it is fundamentally a responsibility of the state, because of the features of this segment being a public service. Taking everything into account, surrounding countries also have European corridors which, in spite of their unfavourable facilities, could divert some of the traffic of Hungarian railway networks if unexpected difficulties in liberalization occur in Hungary.

\section{References}

1. Baldwin, R. [2013]: Regulatory stability and the challenges of re-regulating. Centre on Regulation in Europe

2. Csillik P., Ferenczy E., Galgóczi B., Szabó J. [2000]: Az általános érdekű gazdasági szolgáltatások közös szabályairól, Kézirat

3. Duncan, R. [2012]: The New Depression -The Breakdown of the Paper Money Economy , John Wiley \& Sons Singapore Ptc. Ltd. http://dx.doi.org/10.1002/9781119199199

4. Európai Tanács (2015): Negyedik vasúti csomag http://www.consilium.europa.eu/hu/policies/4th-railway-package/

5. European Comission (2006): Freight Transport Logistics in Europe- the key to sustainable mobility, Commission of the European Communities, Brussels http://eurlex.europa.eu/LexUriServ/LexUriServ.do?uri=COM:2006:0336:FIN:EN:PDF

6. European Comission (2011): White Paper, Roadmap to a Single European Transport Area eur-lex.europa.eu/legal-content/EN/TXT/PDF/?uri=CELEX: 52011DC0144\&from $=$ EN 
7. European Comission (2015): Fact-finding studies in support of the development of an EU strategy for freight transport logistics, Lot 1: Analysis of the EU logistics sector, Final report, ec.europa.eu/transport/themes/strategies/studies/doc/2015-01-freightlogistics-lot1-logistics-sector.pdf

8. Eurostat: http://ec.europa.eu/transport/strategies/facts-and-figures/transportmatters/index_en.htm

9. Gilmor, D. [2014]: State of Logistics Union 2014, Supply Chain Digest, June 17, 2014 http://www.scdigest.com/ASSETS/FIRSTTHOUGHTS/14-06-17.php?cid=8190)

10. Horváth A. - Pónusz M. [2011]: Fuvarozási ágak és szolgáltatók közötti választás elemzése az ellátási lánc müködésének szemszögéböl, In: Erdei Ferenc VI. Tudományos Konferencia. Kecskemét, 2011.Aug. 25-26.. (p.415-4191) ISBN 978-963-7294-98-3 Ö, ISBN 978-615-5192-00-5 (II. kötet)

11. Karmazin Gy. (2015): Logisztikai szolgáltató központokat müködtető vállalkozások fejlesztése hálózati kutatások eredményeinek felhasználásával. In: Karmazin Gy. (föszerk): LOGISZTIKA Trendek és legjobb gyakorlatok, I. évfolyam, 1. szám, Szolnok, 2015. április, pp.14-16.

12. Koós G. [2013]: Piacnyitás a vasúti szektorban- a negyedik vasúti csomag, Verseny és szabályozás 2013.1. szám pp.324-374 MTA Közgazdaságtudományi Intézet, http://econ.core.hu/file/download/vesz/verseny_13_KoosG_vasut.pdf

13. Krugman, P. [2012]: Elég legyen a válságból! Most! Akadémiai Kiadó, 2012

14. Lund, S., Manyika, J., Nyquist, S., Mendonca, L. and Ramaswamy, S. [2013]: Game changers: Five opportunities for US growth and renewal, McKinsey \& Company, http:/www.mckinsey.com/insights/americas/us_game_changers

15. Regulation

in

Europe. http://www.cerre.eu/sites/cerre/files/130204 CERRE Study Stability Final.pdf

16. Schulz, J. D. [2014]: 25th Annual State of Logistics: It's complicated, Logistics management, July 1, 2014 www.logisticsmgmt.com/article/25th_annual_state_of_logistics_its_complicated

17. Valentiny P. [2013]: Változások a hálózatos közszolgáltatások szabályozási intézményrendszerében, Verseny és szabályozás 2013.1.sz. pp.281-318 MTA Közgazdaságtudományi Intézet econ.core.hu/file/download/vesz2013/intezmeny.pdf

\section{Other literature:}

18. Carew, D. D. - Mandel, M. [2014]: Infrastructure Investment and Economic GrowthSurveying New Post-Crisis Evidence, Progressive Policy Institute http://www.progressivepolicy.org/wp-content/uploads/2014/03/2014.03-

Carew_Mandel_Infrastructure-Investment-and-Economic-Growth_Surveying-NewPost-Crisis-Evidence.pdf

19. Európai Bizottság (2014): Közérthetően az Európai Unió szakpolitikáiról, Közlekedéspolitika http://europa.eu/pol/pdf/flipbook/hu/transport_hu.pdf

\section{Principles:}

20. $91 / 440 / \mathrm{EEC}$ content/EN/TXT/PDF/?uri=OJ:L:1991:237:FULL\&from=EN

http://eur-lex.europa.eu/legal-

21. $95 / 19 / \mathrm{EC}$ lex.europa.eu/LexUriServ/LexUriServ.do?uri=CELEX:31995L0019:EN:HTML

22. 2001/12/EC http://eur-lex.europa.eu/legalcontent/EN/TXT/PDF/?uri=CELEX:32001L0012\&from $=\mathrm{EN}$

23. $2001 / 13 / \mathrm{EC}$ content/EN/TXT/PDF/?uri=CELEX:32001L0013\&from=EN
24. $2001 / 14 / \mathrm{EC}$ http://eur-lex.europa.eu/legalcontent/EN/TXT/PDF/?uri=CELEX:32001L0014\&from=EN

http://eur-lex.europa.eu/legal- 
25. $2004 / 49 / \mathrm{EC}$

http://eurlex.europa.eu/LexUriServ/LexUriServ.do?uri=OJ:L:2004:220:0016:0039:EN:PDF

26. $2004 / 51 / \mathrm{EC}$ http://eurlex.europa.eu/LexUriServ/LexUriServ.do?uri=OJ:L:2004:220:0058:0060:EN:PDF

27. $881 / 2004$ http://eurlex.europa.eu/LexUriServ/LexUriServ.do?uri=OJ:L:2004:220:0003:0015:EN:PDF

28. $2007 / 58 / \mathrm{EC}$ http://eurlex.europa.eu/LexUriServ/LexUriServ.do?uri=OJ:L:2007:315:0044:0050:EN:PDF

29. $2007 / 59 / \mathrm{EC}$ http://eurlex.europa.eu/LexUriServ/LexUriServ.do?uri=OJ:L:2007:315:0051:0078:EN:PDF

30. 2013/0014/COD content/EN/TXT/PDF/?uri=CELEX:52013PC0027\&from $=\mathrm{EN}$

http://eur-lex.europa.eu/legal-

31. $2013 / 0015 / \mathrm{COD}$ http://eur-lex.europa.eu/legalcontent/EN/TXT/PDF/?uri=CELEX:52013PC0030\&from $=\mathrm{EN}$

32. $2013 / 0016 / \mathrm{COD}$ http://eur-lex.europa.eu/legalcontent/EN/TXT/PDF/?uri=CELEX:52013PC0031\&from=EN 